\title{
Analysis of Company Development Factors in Manufacturing and Service Company: a Strategic Approach
}

\author{
Jelena Borocki* - Ilija Čosic - Bojan Lalic - Rado Maksimovic \\ University of Novi Sad, Faculty of Technical Sciences, \\ Department of Industrial Engineering and Management, Serbia
}

\begin{abstract}
Continuing company development requires the development of all segments (processes): technology development, organizational structure development, human resources development, investment development, etc. These factors cannot be analyzed irrespective of the external environment. The aim of the presented study was to give contribution to the efforts that are being made to analyze the differences between manufacturing and service companies regarding the selected development factors.

The original contributions of this paper are the analysis of correlations between the elements of a company development and some factors that give us information about the development of the external environment. In a research process modified SPACE analysis for defining strategic posture of the company was used. Basic SPACE analysis (Strategic Position and Action Evaluation - Rowe et al. 1994) is used for analyzing the competitive posture of the company. It consists from four basic dimensions for analyzing external and internal environment: environment stability, industry strength, financial and competitive strength of the company. Modified SPACE analysis is hierarchically structured and it consists of: great number of factors and/or indicators (in order to use analysis in both manufacturing and service companies) assessed through Likert scales in a significance and value domain; assessment of synergy effects of factors and a selection of critical ones; simulation of possible future strategic posture, together with the modification of the values of selected critical factors that could have an impact on the future development of the company.
\end{abstract}

(C)2011 Journal of Mechanical Engineering. All rights reserved.

Keywords: strategy posture, manufacturing companies, service companies, correlations, t-test

\section{INTRODUCTION}

Any qualitative expansion, improvement, and innovation of production, services, structure and technology including a quantitative increase of operation volume (expressed through, for example, sales volume, market share, and company profitability [1]) is a new stage in company development. Continuing company development does not require the development only in terms of new products/services, but also the development of all company segments (processes): technology development, organizational structure development, human resources development, and investment development. It is possible to assume that unequal development level of any of these processes may not ensure company development continuity as a whole regardless of investments, time, and other resources spent for the development of new products/services. It is, therefore, necessary to ensure an integral development process of all processes in a company.

The development of any company, regardless of whether it deals in manufacture or services, requires the company to make a completely new combination of resources and/ or to define completely new (visionary) goals. If a company wants to reach these goals, it has to create an appropriate strategy which has to bring a better competitive position of the company and its better strategic posture in the near future. The key moment of any company's strengths lies within essential and sustainable development. Modern companies require constant investment into development [2].

From a short-term perspective, companies are more interested in growth than in development. However, it is necessary that a company is effective and efficient both in the short- and longterm [3]. Any neglect of the long-term orientation may result in the company's defense strategic

*Corr. Author's Address: University of Novi Sad, Faculty of Technical Sciences,

Trg D. Obradovića 6, Novi Sad, Serbia, borocki@uns.ac.rs 
posture which is only a temporary solution of some critical situation in which the company is found and which must not last for a long time. However, most of the manufacturing companies still assume that product development is enough for company competitiveness. Product development cycle is not a linear one. It is connected with many other functions: marketing, design, process planning, resource planning, etc. Production planning task cannot easily be classified into particular functions and these tasks lead toward integration between these functions [4] and [5].

With regard to the significance of innovations for company development, changes are crucial in implementing the innovation activities as well as in the acceptance of certain (higher) development level. The higher the resistances to the changes in the company are, the lower are the changes and company willingness to initiate the innovation process. Problems of accepting innovation activities requiring the making a good decision and their efficient implementation definitely occur. Changes in the sphere of operation (regardless of the fact whether these are developed countries or countries in transition) are developing faster, where technology development and huge competition having effect at the global level, regardless of physical distance, are the predominant factors. Besides political, ecological, and other conditions for survival, growth and development of any company is important for making adequate strategic decisions whose timeframe is increasingly getting shorter. The prerequisite for making strategic decisions is the knowledge of adequate strategic posture of the company as well as the factors which may be impacted on in order to improve that position, and prepare the company for the next development stage.

How the company will accept and respond to the changes, and how it will create its competitive strategy depends on the quality of the participants in the relevant operating processes. The strategic posture of the company determines the manner in which the company will mobilize its advantages within the market competition and how it will define its competitive advantage [6] and [7]. Therefore, it is very important to know the type of the strategic posture (for example, by implementing the modified strategic planning model - SPACE analysis), and also dynamically monitor the key factors which may impact not only the change of the strategic posture, but also the quality of the development processes at the company, company innovation level, and/or its competitiveness. Modified SPACE analysis includes 81 factors and indicators in order to asses company's current strategic position; it is hierarchically structured and gives company a possibility to monitor every critical factors, make a simulation of a possible future strategic posture, as well as to create a more detailed strategic plan of a future development. Managers are expected to formulate strategies in accordance with the relevant information about the environment [8]. How managers perceive the environment will also reflect in their actions and innovative strategy they choose to pursue. It is important that firms recognize environmental changes and adapt accordingly [9]. Technological and market turbulence are those two moderating effects that influence new product development strategy planning [10]. Thus, it is very important to define business strategy which will in turn lead the company to a higher development level. The strategic role of the production process in creating a business strategy in the company, is becoming so important that we can state that the competitiveness of the company depends on its production characteristics [11].

Many authors have recently stressed that the traditional boundaries between manufacturing and services are becoming obsolete [12] and [13]. Authors have noted that there are new forms of production for supplying physical products together with intangible services [12]. In business life, traditional manufacturing companies have increased their maintenance and other services for the whole lifecycles of their products, while service firms tend to compete with tangible products like "productized" software as well [14]. Some authors claim that there are some differences in service and manufacturing firms in the development of products and services. In addition, there are differences inside the service sector between different types of services as well [15]. This paper deals with the study of the differences between the manufacturing and service companies on the selected geographic area, in view of the level of the development of company processes 
measured through the key company development factors, by applying modified SPACE analysis. The identified similarities and differences result from the implemented research.

Starting from the premise that environment change is a strong driver for organization innovation [16] and for its development, this paper intends to research the relationship between some external development factors and internal (company) development factors. The objective of this study is to examine relationships between the selected factors of internal process development and some factors of external environment development. Some of the selected factors are very important for company innovativeness.

\section{METHOD}

\subsection{Instruments}

SPACE analysis is used to determine appropriate strategic posture of the company or any of its parts (profit centre). However, the existing model [17] and [18] has got certain restrictions:

- insufficiently developed operationalization;

- availability of the information necessary for the strategic posture model;

- variation: there are no guidelines for further activity when the company's strategic posture is once determined (how current posture impacts further development, what opportunities change, etc.).

If the difficulties characteristic of the conditions of the operation in the areas subject to the study are added, like: a lack of understanding of the needs and principles of using the developed methods and techniques of the strategic management, noticeable lag in the development of the external environment which may, to a high extent, impact the level of the company development, a lack of clearly defined development policies, etc., the problem is even more significant and requires finding a method for eliminating these failures and, above all, for ensuring the basis for facilitated, more accurately, and continuing the application of a certain model as a basic simpler formulation and monitoring of the key factors of further company development.
In order to overcome these limitations of the original model, we made some modifications which are achieved in the following areas [19]:

1) A standardization of concepts from strategic management and coordination of all financial terms, according to conditions in selected geographical area has been accomplished.

2) Model is hierarchically structured.

3) After determining the company strategic posture, through applied model, if the gap between the current and desirable posture still exists, a group of factors on which a company has some influence to change them - to improve their values, can be defined.

4) The process of assessment level of influence on the changing factor values from most the significant area for internal dimensions of the company; determine direction and intensity of the resulted vector for changed values and maximal values of every factor from the significant area.

\subsection{Research}

The research covered 126 companies from Serbia, Bosnia \& Herzegovina and Montenegro. With the aim of having as representative a sample as possible, the companies different in their size, legal form of organization, economic sector, location, activity, and ownership have been selected. The research of the strategic commitment of the selected companies was made in line with the expanded and modified SPACE questionnaire [20] to evaluate the company's strategic position. Since the questionnaire covers 80 hierarchical structural factors and/or indicators which are individually evaluated in terms of their level of importance and value for the respondents (for the selected main product/service, target customer, and geographic area), which include various operation areas, it was necessary to complete the questionnaire by several employees from various areas - functional units of the company whose competences, knowledge, and experience in certain fields were used to get as objective an evaluation as possible i.e. significance of a factor and/or indicator from the questionnaire. The survey was conducted for three years on the selected territory. In the final sample of the entities, after the exclusion of the companies 
and factors with more than $5 \%$ of the missing answers, 116 companies were kept in the further analysis. The presentation of the sample structure regarding the type of the company (manufacturing or service) is given in Table 1. Percentages of research example regarding the legal form of the company are given in Fig. 1.

Table 1. Frequency - type of company

\begin{tabular}{|c|c|c|}
\hline & $\begin{array}{c}\text { No. of the } \\
\text { companies }\end{array}$ & Percent \\
\hline Manufacturing & 47 & 40.5 \\
\hline Service & 69 & 59.5 \\
\hline Total & 116 & 100.0 \\
\hline
\end{tabular}

\subsection{Selecting Factors for Research}

The company development certainly depends on a high number of the factors: their selection, assessment of impact to their change with the aim of achieving much higher level of their value, is the starting basis for planning the company's development. Indeed, these factors should be the starting basis of defining the future development goals planning and strategy development - therefore, it is very important that the starting basis, initial evaluation of values and significance of all factors in the company standing analysis, is valid. Of course, not every goal requires the strategy development - there are certain prerequisites for the goal to be of strategic significance for the company (visible income increase, high additional costs for goal achievement, longer term of the goal realization, high risk of achieving the goal, and the need to engage more than $30 \%$ of additional employees).

In the course of the selection of the development factors which are additionally studied in this paper, we were guided by the requirement that all factors are included in the standard set of the indicators of the modified SPACE analysis and that the company may achieve certain impact

Table 2. Results of t-test

\begin{tabular}{|c|c|c|c|c|c|c|c|}
\hline Development factor & Levene $F$ & $P$ & $t$ & $d f$ & $p_{L}$ & $\begin{array}{l}\text { Mean } \\
\text { (prod.) }\end{array}$ & $\begin{array}{c}\text { Mean } \\
\text { (services) }\end{array}$ \\
\hline Market share & .180 & .672 & -.188 & 114 & .851 & 2.9149 & 2.9478 \\
\hline Product/service quality & 5.395 & .022 & $* 2.320$ & 114 & .022 & 3.6064 & 3.3087 \\
\hline Average product/service life cycle stages & .038 & .846 & 1.363 & 109 & .176 & 2.6778 & 2.4212 \\
\hline $\begin{array}{r}\text { Completeness of production programme/ } \\
\text { service programme }\end{array}$ & 2.916 & .090 & 1.279 & 113 & .204 & 3.0543 & 2.8420 \\
\hline Uniqueness (originality) of products/services & 1.775 & .185 & 1.536 & 114 & .127 & 3.0000 & 2.6826 \\
\hline $\begin{array}{r}\text { Capability of introducing new products/ } \\
\text { services }\end{array}$ & .358 & .551 & .801 & 114 & .425 & 3.1277 & 2.9783 \\
\hline Available know-how & .967 & .327 & 1.876 & 114 & .063 & 3.3191 & 2.9942 \\
\hline $\begin{array}{r}\begin{array}{r}\text { Use of capacities in relation to major } \\
\text { competitors }\end{array} \\
\end{array}$ & .641 & .425 & .683 & 114 & .496 & 3.0213 & 2.8986 \\
\hline Product/service development & .015 & .903 & .708 & 113 & .480 & 3.0745 & 2.9426 \\
\hline Operation technology development & 2.757 & .100 & 2.254 & 113 & .026 & 3.2660 & 2.8529 \\
\hline Human resources development & 1.605 & .208 & 1.476 & 114 & .143 & 3.3936 & 3.1449 \\
\hline $\begin{array}{r}\text { Harmonization of org. structure with changes } \\
\text { in the environment/company }\end{array}$ & 7.883 & .006 & 1.590 & 114 & .115 & 3.0426 & 2.7725 \\
\hline Timely taking of corrective actions & .139 & .710 & -.586 & 113 & .559 & 3.1383 & 3.2250 \\
\hline Flexibility in relation to client requirements & .780 & .379 & .589 & 114 & .557 & 3.3830 & 3.3014 \\
\hline Return of investments & .537 & .465 & .929 & 114 & .355 & 3.2447 & 3.0942 \\
\hline Level of cash inflow in terms of self-finance & .272 & .603 & .313 & 114 & .755 & 3.0638 & 3.0058 \\
\hline Placement of interim cash surpluses & .219 & .641 & -.594 & 114 & .554 & 2.2766 & 2.4130 \\
\hline
\end{tabular}

Legende:

Levene $F$ - the value of the Levene test statistic, used to test an assumption of equal variances is valid

$P$ - level of significance

$d f$ - degrees of freedom

$t$ - t-value $(*$ t-test for non-homogenous variances)

Mean (prod.) - arithmetic mean for manufacturing companies 
to their change. The selected factors exclusively describe the company's process development and they could be classified in a four specific company transformation processes: client's relationships, employees, the system of transformations (processes) and finance.

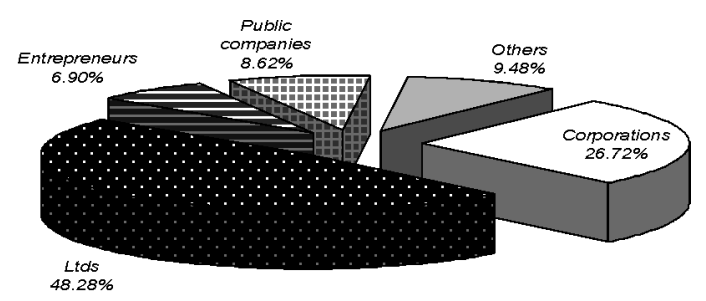

Fig. 1. Sample structure (legal form of the company)

The internal factors show such impact on the company operation and development so that they may be controlled only by the company, under the condition that it has got a well structured organization with clearly defined key characteristics and well developed human resources.

\section{RESULTS}

Each factor of the modified SPACE analysis is assessed in view of its significance and values (during the team work, using Likert scale in specially defined questionnaire). We used $t$-test as the most common used method to evaluate differences in means between two groups: manufacturing and service companies. The purpose of the Levenes Test is to test and verify that this equal variance assumption is reasonable.

$T$-tests for independent samples determine the statistic significance of the difference of the average assessments of the selected factors

Table 3. Matrix of intercorrelations of the selected development factors in the scales of the modified SPACE analysis within the group of manufacturing companies (number of the companies $=47$ ) (significance domain)

\begin{tabular}{|c|c|c|c|c|c|c|}
\hline \multirow[t]{2}{*}{ Development factor } & \multicolumn{2}{|c|}{$\begin{array}{c}\text { Rate of economic } \\
\text { growth in the } \\
\text { country }\end{array}$} & \multicolumn{2}{|c|}{$\begin{array}{c}\text { Technology level } \\
\text { in industrial } \\
\text { segment }\end{array}$} & \multicolumn{2}{|c|}{$\begin{array}{c}\text { Innovation rate } \\
\text { in industrial } \\
\text { segment }\end{array}$} \\
\hline & $r$ & $p$ & $r$ & $p$ & $r$ & $p$ \\
\hline Market share & .011 & .943 & -.001 & .997 & .191 & .198 \\
\hline Product/service quality & .047 & .751 & .255 & .087 & .244 & .099 \\
\hline Average product/service life cycle stages & .051 & .737 & .120 & .438 & .127 & .407 \\
\hline $\begin{array}{r}\text { Completeness of production programme/service } \\
\text { programme }\end{array}$ & .250 & .094 & .066 & .668 & .037 & .809 \\
\hline Uniqueness (originality) of products/services & .192 & .197 & .230 & .125 & .029 & .847 \\
\hline Capability of introducing new products/services & .119 & .425 & .152 & .312 & .166 & .265 \\
\hline Available know-how & .258 & .080 & .201 & .181 & .248 & .093 \\
\hline Use of capacities in relation to major competitors & .009 & .953 & .254 & .089 & .138 & .355 \\
\hline Product/service development & .231 & .119 & .259 & .083 & .301 & .040 \\
\hline Operation technology development & .146 & .326 & .269 & .071 & .215 & .147 \\
\hline Human resources development & -.048 & .750 & .075 & .623 & .273 & .064 \\
\hline $\begin{array}{r}\text { Harmonization of organizational structure with } \\
\text { changes in the environment/company }\end{array}$ & .257 & .081 & -.067 & .658 & .227 & .125 \\
\hline Timely taking of corrective actions & -.046 & .759 & -.108 & .476 & .273 & .064 \\
\hline Flexibility in relation to client requirements & .113 & .448 & -.123 & .415 & .369 & .011 \\
\hline Return of investments & -.164 & .270 & .167 & .267 & .145 & .330 \\
\hline Level of cash inflow in terms of self-finance & -.006 & .969 & -.120 & .426 & .115 & .442 \\
\hline Placement of interim cash surpluses & .059 & .694 & .129 & .393 & .036 & .810 \\
\hline Rate of economic growth in the country & 1 & & .101 & .503 & .152 & .308 \\
\hline Technology level in industrial segment & .101 & .503 & 1 & & .151 & .317 \\
\hline Innovation rate in industrial segment & .152 & .308 & .151 & .317 & 1 & \\
\hline
\end{tabular}


(within the significance domain) between the manufacturing and service companies. In the course of analysis, the grouping (independent) variable included the activity (manufacturing/ service) while the set of the variables included the scores at the selected development factors. It is presented in Table 2.

Statistically significant difference between the manufacturing and service companies in terms of the significance of development factors is obtained only for the factors Product/service quality and Operation technology development.

$T$-tests are significant at the level of $p<0.05$. Based on the values of arithmetic means of these factors, it may be seen that the manufacturing companies place a higher significance to these factors.
2.1 Relations of Significance of the Selected Factors of Company Development and Selected Factors of External Environment Development on the Sub-samples of Manufacturing and Service Companies

This relation was specifically checked using Pearson's linear correlation coefficient on the sub-sample of the manufacturing and the subsample of service companies.

The results show that there is certain correlation degree of low intensity in the sample of the manufacturing companies between the factors: Product/service development and Innovation rate in industrial segment, i.e. the factor: Flexibility in relation to client requirements and Innovation rate in industrial segment. It is obvious that the rate of innovation in the commercial segment is significant for the stating of the significance of the above factors. Manufacturing companies state that the higher the Innovation rate in industrial/commercial

Table 4. Matrix of intercorrelations of the selected development factors in the scales of the modified SPACE analysis within the group of service companies (number of the companies $=69$ ) (significance domain)

\begin{tabular}{|c|c|c|c|c|c|c|}
\hline \multirow[t]{2}{*}{ Development factor } & \multicolumn{2}{|c|}{$\begin{array}{c}\text { Rate of economic } \\
\text { growth in the } \\
\text { country }\end{array}$} & \multicolumn{2}{|c|}{$\begin{array}{c}\text { Technology level } \\
\text { in industrial } \\
\text { segment }\end{array}$} & \multicolumn{2}{|c|}{$\begin{array}{l}\text { Innovation rate in } \\
\text { industrial segmen }\end{array}$} \\
\hline & $r$ & $p$ & $r$ & $p$ & $r$ & $p$ \\
\hline Market share & .012 & .924 & .316 & .008 & .342 & .004 \\
\hline Product/service quality & .028 & .821 & .251 & .037 & .188 & .123 \\
\hline Average product/service life cycle stages & .033 & .794 & .160 & .199 & .189 & .128 \\
\hline Completeness of production/service programme & .002 & .987 & .168 & .169 & .201 & .098 \\
\hline Uniqueness (originality) of products/services & .059 & .631 & .151 & .216 & .291 & .015 \\
\hline Capability of introducing new products/services & -.112 & .360 & .265 & .028 & .344 & .004 \\
\hline Available know-how & .190 & .117 & .362 & .002 & .454 & .000 \\
\hline Use of capacities in relation to major competitors & .085 & .488 & .300 & .012 & .492 & .000 \\
\hline Product/service development & .118 & .337 & .319 & .008 & .391 & .001 \\
\hline Operation technology development & .065 & .599 & .323 & .007 & .432 & .000 \\
\hline Human resources development & .040 & .745 & .249 & .039 & .288 & .017 \\
\hline $\begin{array}{r}\text { Harmonization of organizational structure with changes } \\
\text { in the environment/company }\end{array}$ & .139 & .254 & .177 & .147 & .142 & .243 \\
\hline Timely taking of corrective actions & .156 & .203 & .066 & .595 & .132 & .283 \\
\hline Flexibility in relation to client requirements & .014 & .906 & -.055 & .651 & .168 & .168 \\
\hline Return of investments & .238 & .049 & .130 & .286 & .252 & .037 \\
\hline Level of cash inflow in terms of self-finance & .081 & .507 & .280 & .020 & .374 & .002 \\
\hline Placement of interim cash surpluses & .096 & .431 & .312 & .009 & .191 & .116 \\
\hline Rate of economic growth in the country & 1 & & -.125 & .307 & -.002 & .988 \\
\hline Technology level in industrial segment & -.125 & .307 & 1 & & .510 & .000 \\
\hline Innovation rate in industrial segment & -.002 & .988 & .510 & .000 & 1 & \\
\hline
\end{tabular}


segment, the more significant is the factors such as Product/service development and Flexibility in relation to client requirements. Observing the sample of the service companies, it is noticed that there is a positive correlation of low to moderate intensity between the selected external environment development factors: Technology level in commercial segment and Innovation level in industrial/commercial segment with the internal environment development factors: Market share, Capability of introducing new products/ services, Available know-how, Use of capacities in relation to major competitors, Product/service development, Operation technology development, and Human resources development, Level of cash inflow in terms of self-finance (Table 4). Within the group of the non-manufacturing companies, in the matrix of the intercorrelations of the dimensions of significance from the area of the modified SPACE analysis, 19 correlation coefficients are statistically significant in relation to 2 within the group of the manufacturing companies. The consideration of the intercorrelation matrices indicates that there are differences in the signs of the correlation coefficients; however, the differences in the intensity of the individual bivariant relations between the modified SPACE analysis dimensions are visible.

\subsection{Relation of Development Factors of Modified SPACE Analysis from the Domain of Values and Development Factors of External Environment}

This relation was specifically checked using Pearson's linear correlation coefficient on the sub-sample of the manufacturing and the subsample of service companies.

In the sub-sample of the manufacturing companies, there is a negative correlation of moderate intensity between Available know-how and Rate of economic growth in the country, as well as between the Placement of interim cash surpluses and Rate of economic growth.

Table 5. Matrix of intercorrelations of the selected development factors in the scales of the modified SPACE analysis within the group of manufacturing companies (number of the companies $=47$ ) (value domain)

\begin{tabular}{|c|c|c|c|c|c|c|}
\hline \multirow[t]{2}{*}{ Development factor } & \multicolumn{2}{|c|}{$\begin{array}{c}\text { Rate of economic } \\
\text { growth in the } \\
\text { country }\end{array}$} & \multicolumn{2}{|c|}{$\begin{array}{l}\text { Technology level in } \\
\text { industrial segment }\end{array}$} & \multicolumn{2}{|c|}{$\begin{array}{l}\text { Innovation rate in } \\
\text { industrial segment }\end{array}$} \\
\hline & $r$ & $p$ & $r$ & $p$ & $r$ & $p$ \\
\hline Market share & -.297 & .264 & .263 & .074 & .098 & .512 \\
\hline Product/service quality & -.472 & .065 & .575 & .000 & .501 & .000 \\
\hline Average product/service life cycle stages & -.153 & .602 & .131 & .393 & .409 & .005 \\
\hline Completeness of production/service programme & .311 & .242 & .107 & .474 & .004 & .979 \\
\hline Uniqueness (originality) of products/services & -.013 & .962 & .222 & .134 & .264 & .073 \\
\hline Capability of introducing new products/services & -.205 & .447 & .162 & .276 & .531 & .000 \\
\hline Available know-how & -.510 & .044 & .272 & .065 & .233 & .115 \\
\hline Use of capacities in relation to major competitors & -.072 & .792 & .207 & .164 & .402 & .005 \\
\hline Product/service development & -.132 & .626 & .377 & .009 & .451 & .001 \\
\hline Operation technology development & -.088 & .745 & .457 & .001 & .498 & .000 \\
\hline Human resources development & -.139 & .607 & .377 & .009 & .322 & .027 \\
\hline $\begin{array}{r}\text { Harmonization of organizational structure with } \\
\text { changes in the environment/company }\end{array}$ & -.009 & .972 & .322 & .028 & .489 & .000 \\
\hline Timely taking of corrective actions & -.141 & .601 & .411 & .004 & .269 & .067 \\
\hline Flexibility in relation to client requirements & -.183 & .499 & .168 & .260 & .168 & .259 \\
\hline Return of investments & -.093 & .732 & .512 & .000 & .279 & .057 \\
\hline Level of cash inflow in terms of self-finance & -.119 & .661 & .248 & .092 & -.081 & .586 \\
\hline Placement of interim cash surpluses & -.545 & .036 & .298 & .046 & .334 & .025 \\
\hline Rate of economic growth in the country & 1 & & -.133 & .624 & .148 & .584 \\
\hline Technology level in industrial segment & -.133 & .624 & 1 & & .365 & .012 \\
\hline Innovation rate in industrial segment & .148 & .584 & .365 & .012 & & 1 \\
\hline
\end{tabular}


Table 6. Matrix of intercorrelations of the selected development factors in the scales of the modified SPACE analysis within the group of service companies (number of the companies $=69)$ (value domain)

\begin{tabular}{|c|c|c|c|c|c|c|}
\hline \multirow[t]{2}{*}{ Development factor } & \multicolumn{2}{|c|}{$\begin{array}{c}\text { Rate of economic } \\
\text { growth in the } \\
\text { country }\end{array}$} & \multicolumn{2}{|c|}{$\begin{array}{l}\text { Technology level in } \\
\text { industrial segment }\end{array}$} & \multicolumn{2}{|c|}{$\begin{array}{l}\text { Innovation rate in } \\
\text { industrial segment }\end{array}$} \\
\hline & $r$ & $p$ & $r$ & $p$ & $r$ & $p$ \\
\hline Market share & .648 & .023 & .307 & .010 & .352 & .003 \\
\hline Product/service quality & .143 & .658 & .211 & .082 & .275 & .022 \\
\hline Average product/service life cycle stages & -.392 & .233 & .265 & .032 & .094 & .454 \\
\hline Completeness of production/service programme & .201 & .531 & .152 & .212 & .318 & .008 \\
\hline Uniqueness (originality) of products/services & -.083 & .799 & .088 & .472 & .177 & .145 \\
\hline Capability of introducing new products/services & .335 & .287 & .083 & .498 & .304 & .011 \\
\hline Available know-how & .225 & .482 & .387 & .001 & .355 & .003 \\
\hline Use of capacities in relation to major competitors & .205 & .523 & .168 & .171 & .287 & .018 \\
\hline Product/service development & .413 & .183 & .243 & .044 & .289 & .016 \\
\hline Operation technology development & -.017 & .958 & .173 & .155 & .181 & .137 \\
\hline Human resources development & .364 & .245 & .248 & .040 & .312 & .009 \\
\hline $\begin{array}{r}\text { Harmonisation of organizational structure with } \\
\text { changes in the environment/company }\end{array}$ & .429 & .164 & .175 & .151 & .292 & .015 \\
\hline Timely taking of corrective actions & .427 & .166 & .204 & .092 & .312 & .009 \\
\hline Flexibility in relation to client requirements & .158 & .624 & .130 & .286 & .224 & .065 \\
\hline Return of investments & .198 & .537 & .418 & .000 & .383 & .001 \\
\hline Level of cash inflow in terms of self-finance & .264 & .407 & .144 & .239 & .159 & .192 \\
\hline Placement of interim cash surpluses & -.301 & .341 & .300 & .014 & .199 & .107 \\
\hline Rate of economic growth in the country & 1 & & .500 & .098 & .497 & .100 \\
\hline Technology level in industrial segment & .500 & .098 & 1 & & .576 & .000 \\
\hline Innovation rate in industrial segment & .497 & .100 & .576 & .000 & 1 & \\
\hline
\end{tabular}

Significant positive correlation of moderate intensity exists between the factors: Product/ service quality, Product/service development, Operation technology development, Capability of introducing new products/services, Harmonization of organizational structure with changes in the environment/company, Use of capacities in relation to major competitors with the Innovation rate in industrial segment.

The significant positive correlation of moderate intensity exists between the factors: Product/service development, Operation technology development, Timely taking of corrective actions, Return of investments, with the Technology level in industrial/commercial segment. Within the group of the manufacturing companies, in the matrix of the intercorrelations of the dimensions of values from the area of the modified SPACE analysis, 16 correlation coefficients are statistically significant which is shown in Table 5, in relation to 2 correlation coefficients in the matrix of the intercorrelations of the dimensions of significance, presented in Table 3 for the same group.

In the sub-sample of the service companies, there are certain significant correlations of low intensity, except between the factors Market share and Rate of economic growth in the country (high correlation), shown in Table 6.

The significant positive correlation of moderate intensity exists between the factors: Product/service development and Technology level in industrial/commercial segment exists in the sub-sample of the manufacturing companies but not in the sub-sample of the service companies for which the correlation of moderate intensity between Market share and Rate of economic growth in the country (these correlation 
coefficients have the highest value in both Matrix of intercorrelations) is statistically significant.

Differences in the structure of the correlation matrices prove that the interaction patterns among the selected development factors of the modified SPACE analysis, most probably, differ in the groups of the manufacturing and nonmanufacturing companies.

\section{DISCUSSION}

The results of the research indicate that the difference between the manufacturing and service companies is reflected in the fact that the manufacturing companies place higher significance to the development factors: Product quality and Operation technology development. It may be assumed that the service companies within the selected area of the research place higher significance to other development factors, i.e. that they observe the level of their development through some other factors than those included in the modified SPACE analysis.
In terms of the degree of the relation of the selected company development factors with the level of external environment factors development, but within the domain of the significance placed by the companies to these factors, the main differences between manufacturing and service companies are given in Table 7 , where the big size of sign " $\mathrm{X}$ " signals a moderate level of correlation (others are low).

Obviously, the manufacturing companies perceive that the significance of these internal development factors is ensured through internal activities, based on a company's own potentials, rather than based on the economic growth rate: there is no significant correlation with this external factor, for both manufacturing and service companies.

The service companies perceive that the Technology level and Innovation rate in industrial/ commercial segment to a large extent determine the level of significance of almost all internal development factors which is not the case with manufacturing companies. Service companies

Table 7. Differences between manufacturing and service companies in relation to Innovation rate in industrial segment and Technology level in industrial segment (significance domain)

\begin{tabular}{|c|c|c|c|c|}
\hline \multirow{2}{*}{ Development factor } & \multicolumn{2}{|c|}{$\begin{array}{l}\text { Innovation rate in industrial } \\
\text { segment }\end{array}$} & \multicolumn{2}{|c|}{$\begin{array}{l}\text { Technology level in } \\
\text { industrial segment }\end{array}$} \\
\hline & $\begin{array}{c}\text { Manuf. } \\
\text { companies }\end{array}$ & $\begin{array}{c}\text { Service } \\
\text { companies }\end{array}$ & $\begin{array}{c}\text { Manuf. } \\
\text { companies }\end{array}$ & $\begin{array}{c}\text { Service } \\
\text { companies }\end{array}$ \\
\hline Market share & & $\mathrm{x}$ & & $\mathrm{x}$ \\
\hline Product/service quality & & & & $\mathrm{x}$ \\
\hline \multicolumn{5}{|l|}{ Average product/service life cycle stages } \\
\hline \multicolumn{5}{|l|}{ Completeness of production/service programme } \\
\hline Uniqueness (originality) of products/services & & $\mathrm{x}$ & & \\
\hline Capability of introducing new products/services & & $\mathrm{x}$ & & $\mathrm{x}$ \\
\hline Available know-how & & $\mathrm{X}$ & & $\mathrm{x}$ \\
\hline Use of capacities in relation to major competitors & & $\mathrm{X}$ & & $\mathrm{x}$ \\
\hline Product/service development & $\mathrm{x}$ & $\mathrm{x}$ & & $\mathrm{x}$ \\
\hline Operation technology development & & $\mathrm{X}$ & & $\mathrm{x}$ \\
\hline Human resources development & & $\mathrm{x}$ & & $\mathrm{x}$ \\
\hline \multicolumn{5}{|l|}{$\begin{array}{r}\text { Harmonization of org. structure with changes in the } \\
\text { environment/company }\end{array}$} \\
\hline \multicolumn{5}{|l|}{ Timely taking of corrective actions } \\
\hline Flexibility in relation to client requirements & $\mathrm{x}$ & & & \\
\hline Return of investments & & $\mathrm{x}$ & & \\
\hline Level of cash inflow in terms of self-finance & & $\mathrm{x}$ & & $\mathrm{x}$ \\
\hline Placement of interim cash surpluses & & & & $\mathrm{x}$ \\
\hline
\end{tabular}


Table 8. Differences between manufacturing and service companies in relation to Innovation rate in industrial segment and Technology level in industrial segment (value domain)

\begin{tabular}{|c|c|c|c|c|}
\hline \multirow{2}{*}{ Development factor } & \multicolumn{2}{|c|}{$\begin{array}{l}\text { Innovation rate in } \\
\text { industrial segment }\end{array}$} & \multicolumn{2}{|c|}{$\begin{array}{l}\text { Technology level in } \\
\text { industrial segment }\end{array}$} \\
\hline & $\begin{array}{c}\text { Manuf. } \\
\text { companies }\end{array}$ & $\begin{array}{c}\text { Service } \\
\text { companies }\end{array}$ & $\begin{array}{c}\text { Manuf. } \\
\text { companies }\end{array}$ & $\begin{array}{c}\text { Service } \\
\text { companies }\end{array}$ \\
\hline Market share & & $\mathrm{x}$ & & $\mathrm{x}$ \\
\hline Product/service quality & $\mathrm{X}$ & $\mathrm{x}$ & $\mathrm{X}$ & \\
\hline Average product/service life cycle stages & & & & $\mathrm{x}$ \\
\hline Completeness of production/service programme & & $\mathrm{x}$ & & \\
\hline \multicolumn{5}{|l|}{ Uniqueness (originality) of products/services } \\
\hline Capability of introducing new products/services & $\mathrm{X}$ & $\mathrm{x}$ & & \\
\hline Available know-how & & $\mathrm{x}$ & & $\mathrm{x}$ \\
\hline Use of capacities in relation to major competitors & $\mathrm{X}$ & $\mathrm{x}$ & & \\
\hline Product/service development & $\mathrm{X}$ & $\mathrm{x}$ & $\mathrm{x}$ & $\mathrm{x}$ \\
\hline Operation technology development & $\mathrm{X}$ & & $\mathrm{X}$ & \\
\hline Human resources development & $\mathrm{x}$ & $\mathrm{x}$ & $\mathrm{x}$ & $\mathrm{x}$ \\
\hline $\begin{array}{r}\text { Harmonization of org. structure with changes in the } \\
\text { environment/company }\end{array}$ & $\mathrm{X}$ & $\mathrm{x}$ & $\mathrm{x}$ & \\
\hline Timely taking of corrective actions & & $\mathrm{x}$ & $\mathrm{X}$ & \\
\hline \multicolumn{5}{|l|}{ Flexibility in relation to client requirements } \\
\hline Return of investments & & $\mathrm{X}$ & $\mathrm{X}$ & $\mathrm{x}$ \\
\hline \multicolumn{5}{|l|}{ Level of cash inflow in terms of self-finance } \\
\hline Placement of interim cash surpluses & $\mathrm{x}$ & & $\mathrm{x}$ & $\mathrm{x}$ \\
\hline
\end{tabular}

considered that external development significantly affect on the level of internal development, measured through selected factors (available know-how, operation technology development, originality of services, etc.).

In terms of the value of the selected company factors, service companies perceive that the Market share size significantly depends on the Rate of economic growth - the higher the rate of economic growth, the higher market share may be achieved, in contrast to the manufacturing companies which neglect both the significance of this factor and its value (Table 8).

Another difference is reflected in the fact that a high rate of economic growth for the manufacturing companies does not also mean a highly available know-how. For service companies, Available knowhow depends on the Technology level and Innovation rate in industrial/commercial segment. Both manufacturing and service companies do not see the level of the rate of economic growth with the majority of factors (apart from the market share with the service companies) as important for a strong development of the selected factors of company development.
Flexibility in relation to client requirements, Uniqueness (originality) of products/services and Level of cash inflow in terms of self-finance does not depend on the value of the Rate of economic growth in the country, Technology level in industrial segment and Innovation rate in industrial segment for any company from the research sample. These company development factors probably depend on some other factors (i.e. creativity climate in the company; knowledge of the service employees; technological, capacity and flows flexibility of the company [21] to [23]; financial strength of the company, etc.).

The main similarities between manufacturing and service companies are expressed in correlation coefficients which exist between internal development factors: Product/service development and Human resources development and external development factors: Technology level and Innovation rate in industrial segment. This means that manufacturing and service companies stand that high quality of product or service could be reached only when high technology exists in 
external environment in which innovation rate is also high. Capability of introducing new products or service is possible only if the innovation rate in the external environment is high. Return of investments depends only from Technology level in industrial segment for selected companies in a research sample. Considering the above, it can be concluded that it is possible to define the collective set of company development factors that depends on the same external factors for both manufacturing and service companies. This set includes: Product/service development, Human resources development, Capability of introducing new products or service and Return of investments. Rate of economic growth in the country does not have an impact on these factors.

The development of a new product is conducted in accordance with the strategy and market needs. The fact that it requires significant financial and other resources, underpin applying of a multicriteria analysis of product development in a multi-dimensional space [24].

\section{CONCLUSION}

Statistic analyses of $t$-test and linear correlation were used on the selected sample of 116 companies, thereof, 47 are manufacturing and 69 are service companies, with the aim of determining possible differences regarding the attitude of these companies in relation to the significance of the selected factors of process development at company and external environment, and it may be concluded that there are certain differences in the perception of the significance of the development factors between the manufacturing and service companies. It was identified that there was the application of the modified SPACE analysis as a basis to determine possible differences between the manufacturing and service companies in terms of the selected development factors. These differences are also perceivable in terms of the factor value. The manufacturing companies from the selected sample see their development mostly through quality product development and operation technology, and they place lower significance on other development factors i.e. their processes. This could mean that the manufacturing companies, to some extent, neglect other development processes and do not monitor their development through certain indicators of competitive and financial potential which is given a higher significance by the service companies. It could be said that the service companies in the selected geographic area are more developed regarding the selected development factors than the manufacturing, i.e. there is certain integral development approach to the company development as a whole.

Manufacturing companies in the selected sample of research have as a dominant (most frequent), an aggressive strategic posture, which means that the company has at the same time excellent financial and competitive potential, which in turn means a higher level of product development as good as most of the company's processes. However, with a more detailed analysis of strategic posture, especially of the direction (position) of the resultant, it is obvious that the services companies has a stronger, more stable aggressive posture than the manufacturing companies, whose resultants are close to the scale that represents industrial strength. Such a posture of the manufacturing companies indicates that the company is an early adopter of aggressive strategic posture and has not yet well settled into this posture (position of a stable balance). It is closer to the competitive strategic posture with the main characteristic: attractive industry in a relatively unstable environment. Research and development activities in the company require a lot of resources and are not cheap, particularly in a case of product development. Creating better strategic posture requires a company to mobilize a lot of internal resources. Creating a plan of future company development is more complicated. The simulation of values of key development factors gives valuable information about the possible future strategic posture to the company. For this reason, it is useful to use a process of simulation (as we can use some kind of simulation in modified SPACE analysis in order to find out if company could reach its most desired strategic posture). Thus, in a company with low cost strategy, created ideas should be manifested in the form of process innovation and not in product/ service innovation. In addition to the aggressive and competitive posture, a company can have defensive and conservative posture applying SPACE analysis. In the research sample, $45.69 \%$ 
of selected companies have an aggressive posture, $20.69 \%$ competitive, $26.72 \%$ defensive and $6.90 \%$ have a conservative posture. On the other hand, good aggressive posture allows company to protect its competitive advantage and to increase its market share. The results of the research show that service companies give a higher importance to market share while manufacturing companies are not. On the base of research results, it could be assumed that manufacturing and service companies give more importance to product and market/clients respectively. If service companies are focused only on their clients and markets and do not invest enough in the development of internal processes, innovation radicalness will be restricted and consequently company development might become critical. On the other hand, if manufacturing companies will pay attention only on their products, their market orientation and innovativeness of business systems will be put into critical position. As we assume, there are some differences in service and manufacturing companies in the development of products and services, as good as in development of other internal processes.

In an unstable environment companies are forced to be more innovative. However, they put more emphasis on administrative innovations, mostly because a frequent change even in external environment requires frequent changes of structures and systems. Service companies from the research example have a stronger aggressive posture than the manufacturing one, which allows the company to be innovative (even to introduce radical innovations), thus to improve its level of development.

The manufacturing and service companies from the research sample are considering that external environment is highly unstable (70\% of manufacturing and $67 \%$ of service companies). Rate of economic growth in the country was evaluated as under mediate in $72 \%$ of manufacturing companies and in $71 \%$ of service companies. Taking Technology level and Innovation rate in industrial segment as selected factors of external environment development were also evaluated with an under-average level but at a lower percentage (almost 40\%) for both manufacturing and service companies. Service companies evaluated industry strength lower than manufacturing companies.

Strategic posture is a major determinant for innovativeness. A firm's choice of an aggressive, competitive, risk taking strategy apparently influences innovativeness in terms of the way the firms differentiate themselves from their competitors by changing their production methods and products. The company's choice of an aggressive strategy leads to a flexible model of organizational structure.

Strategic plan of the company development could be defined on the basis of selected critical factors of company development. Simulation of their value change through the process of applying modified SPACE analysis, gives the company an insight on possible and/or idealistic future strategic posture. More valuable is the possibility to monitor how changes of value of key development factors affect the development plan of the company, its structure and strategic posture.

There are certain restrictions of this research reflected in the following:

- selection of factors is based on the application of a model for the evaluation of the strategic posture of the companies,

- number of the companies in the sample is insufficient for the application of other statistical analyses,

- information on the factors of underdevelopment of the external environment is insufficient.

Also, in the course of the selection of the development factors to be observed, various factors must be taken in consideration:

- company life cycle stage (which gives information on the characteristics of the organizational and key problems),

- external environment development degree (knowledge of the environment characteristics in detail),

- internal environment development degree (defined through the competitive and financial potential of the company; production structure, and its changes, etc.),

- competition (number, intensity, etc.),

- trends and further movements on the selected markets.

Overcoming of the existing restrictions is possible in the further research with a greater 
number of companies in the sample, using a larger number of factors that could give us more information about internal and/or external development level, and with a more detail analysis of service/manufacturing sector's structure (specially because service industry is highly fragmented). That will help to identify the specific differences between both sectors.

\section{REFERENCES}

[1] Prajogo, D. (2006). The relationship between innovation and business performance - a comparative study between manufacturing and service firms. Knowledge and process management, vol. 13, no. 3, p. 218-225.

[2] Kostanjevec, T., Polajnar, A., Sarjaš, A. (2008). Product development through multicriteria analysis. Strojniški vestnik - Journal of Mechanical Engineering, vol. 54, no. 11, p. $739-750$.

[3] Adizes, I. (2005). The Pursuit of Prime. The Adizes Institute Publishing, Santa Monica, CA: Knowledge Exchange.

[4] Gecevska, V., Cus, F., Dukovski, V., Kuzinovski, M. (2006). Modeling of manufacturing activities by process planning knowledge representation. Int. j. simul. model., vol. 5, no. 2, p. 69-81.

[5] Palčič, I., Polajnar, A., Pandža, K. (2003). A model for the effective management of orderbased production. Strojniški vestnik - Journal of Mechanical Engineering, vol. 49, no. 7/8, p. 398-412.

[6] Thoumrungroje, A., Tansuhaj, P. (2005). Entrepreneurial strategic posture, international diversification, and firm performance. Multinational Business Review, vol. 13, no. 1, p. 55-73.

[7] Pandža, K., Buchmeister, B., Polajnar, A., Palčič, I. (2002). An operations strategy supported with resource-based theory: a case study at the Primat company. Strojniški vestnik - Journal of Mechanical Engineering, vol. 48, no. 7, p. 379-394.

[8] Rajkovič, T., Vehovec, M. (2008). Competencies and innovative performance of Croatian manufacturing companies. EIZ
Working Papers EIZ-WP-0802, p. 5-25, Zagreb.

[9] Leonard-Barton, D.A. (1992). Core capabilities and core rigidities: a paradox in managing new product development. Strategic Management Journal, vol. 13, no. 1, p. 111-125.

[10] Calantone, R., Garcia, R., Dröge, C. (2003). The effects of environmental turbulence on new product development strategy planning. Journal of Product Innovation Management, vol. 20, p. 90-103.

[11] Lalic, B., Cosic, I., Anisic, Z. (2005). Simulation based design and reconfiguration of production systems. Int. j. simul. model., vol. 4, no. 4, p. 173-183.

[12] Gann, D.M., Salter, A.J. (2003). Innovation in design, engineering and project management services. Tidd, J., Hull, F.M. (Eds.), Service innovation: organizational responses to technological opportunities and market imperatives, Series on Technology Management, vol. 9, p. 301-320.

[13] Drejer, I. (2004). Identifying innovation in surveys of services: a Schumpeterian perspective. Research Policy, no. 33, p. 551562.

[14] Davies, A., Brady, T., Hobday, M. (2006). Charting a path toward integrated solutions. MIT Sloan Management Review, vol. 47, no. 3, p. 39-48.

[15] Atuahene-Gima, K. (1996). Differential potency of factors affecting innovation performance in manufacturing and services firms in Australia. J. Prod. Innov. Management, vol. 13, p. 35-52.

[16] Damanpour, F., Gopalakrishnan, G. (1998). Theories of organizational structure and innovation adoption: the role of environmental change. Journal of Engineering and Technology Management, vol. 15, p. 1-24.

[17] Rowe, J.A., Mason, O.R., Dickel, E.K., Mann, B.R., Mockler, J.R. (1994). Strategic management - a methodological approach. $4^{\text {th }}$ edition, Addison-Wesley Publishing Company, Reading.

[18] Rowe, J.A., Mason, O.R., Dickel, E.K. (1984). Computer models for strategic 
management. Addison-Wesley Publishing Company, Reading.

[19] Borocki, J. (1998). Determination strategic posture of the company. Master Thesis, University of Novi Sad, Faculty of Technical Sciences, Novi Sad.

[20] Borocki, J. (2009). Developing strategic planning model in function of company's innovativeness. $\mathrm{PhD}$ Thesis, University of Novi Sad, Faculty of Technical Science, Novi Sad.

[21] Fricke, E., Schulz, A., Wenzel, S., Negele, H. (2000). Design for changeability of integrated systems within a hypercompetitive environment. Conference: Systems Approach to Product Innovation and Development in
Hyper-Competitive Environments, INCOSE, Colorado.

[22] Schulz, A.P., Fricke, E. (1999). Incorporating flexibility, agility, robustness, and adaptability within the design of integrated systems - key to success? 18th DASC, Gateway to the New Millenium, IEEE.

[23] Zelenović, D.M. (1982). Flexibility - A Condition for Effective Production Systems. International Journal of Production Research, vol. 20, no. 3, p. 319-337.

[24] Kostanjevec, T., Polajnar, A., Kostanjevec, M. (2009). Product development simulation with multicriteria analysis. Int. $j$. simul. model., vol. 8, no. 1, p. 38-47. 